\title{
Foreign body traumas of the eye managed in an emergency department of a single-institution
}

\author{
Bir merkezin acil servisinde tedavi edilen gözün yabancı cisim travmaları
}

\author{
Özlem Yİ̆̈iT, Aslıhan YÜRÜKTÜMEN, Savaş ARSLAN
}

\section{BACKGROUND}

Superficial corneal foreign bodies (SCFB) are common injuries seen in the ED. The aim of this study was to describe the eye injuries caused by FBs and to determine clinical strategies for the prevention and management of ocular trauma.

\section{METHODS}

This was a retrospective chart review of the previous two years. Demographic data, timing of the injury, injury type (open- or closed-globe injuries), source of the FB, hospital admission and ophthalmology consultation, treatments, and the long-term complications were recorded for each patient.

\section{RESULTS}

There were 476 patients, and $83 \%$ were male, with an average age of $34.16 \pm 14.02$ years. $9.7 \%$ of the eyes had an open-globe injury, while the rest were closed-globe injuries with or without SCFB. The most common FBs were metal fragments $(37.6 \%)$ and dust $(31.1 \%)$. The majority of the patients $(72.1 \%)$ sustained work-related injuries. $42.4 \%$ of the patients were consulted to ophthalmology, and the remaining were treated by the emergency physicians. Only $10 \%$ of the patients required hospitalization, and complications were seen in $2.3 \%$ of the patients.

\section{CONCLUSION}

Ocular FB involved mainly young healthy males who had sustained work-related injuries. In view of the large number of eye injuries seen in EDs, ED colleagues should train themselves in order to appropriately recognize, treat and refer the SCFB injuries seen in the ED.

Key Words: Emergency department; eye; foreign body; treatment.

\begin{abstract}
$A M A C ̧$
Yüzeysel korneal yabancı cisimler acil servise sık başvuran olgulardır. $\mathrm{Bu}$ çalışmanın amacı, acil servise yabancı cisimlerle oluşan göz travmasıyla başvuran olguları tanımlamak ve göz travmasının önlenmesi ve acil servis yönetim stratejilerini tartışmaktır.
\end{abstract}

\section{GEREÇ VE YÖNTEM}

Çalışma geçmiş iki yılın kayıtları incelenerek geriye dönük olarak yapıldı. Demografik bilgiler, yaralanma zamanı, yaralanma tipi (açık veya kapalı glob yaralanması), yabancı cismin ne olduğu, hastane yatış ve oftalmoloji konsültasyonu varlığı, uygulanan tedaviler ve geç dönemde görülen kalicı hasarlar kaydedildi.

\section{BULGULAR}

Toplam 476 hasta çalışmaya alındı, hastaların \%83'ü erkekti, ortalama yaş 34,16 $\pm 14,02$ idi. Yaralanmaların \%9,7'si açık glob yaralanması iken, kalanlar yüzeysel yabancı cisim bulunan veya bulunmayan kapalı yaralanmalardı. En sık görülen yabancı cisimler metal çapakları $(\% 37,6)$ ve toz $(\% 31,1)$ olarak saptand. Hastaların çoğunda $(\% 72,1)$ iş yerinde yaralanma söz konusuydu. Hastaların \%42,4’ü oftalmoloji ile konsülte edilirken, diğer hastalar acil tıp asistan ve uzmanları tarafindan tedavi edildi. Hastaların \%10'u hastaneye yatırıldı ve \%2,3'ünde uzun dönemde komplikasyon görüldü.

\section{SONUÇ}

Göz yabancı cisim travmaları en çok genç sağlıklı erkeklerin, iş nedenli yaralanmaları olarak oluşmaktadır. Çok sayıda göz travması acil servislerde görüldüğü için, acil servis hekimleri yüzeysel korneal yabancı cisimlerin tanınması, tedavisi ve yönetimi konusunda eğitilmelidir.

Anahtar Sözcükler: Acil servis; göz; yabancı cisim; tedavi. 
Ocular trauma is a leading cause of visual impairment and impacts both the individual by affecting their quality of life and the community by causing loss of working capacity. The epidemiology of eye trauma has been well described in developed countries, and the lifetime prevalence of ocular injuries is estimated to be $14.4 \%$ to $19.8 \%$ in the United States. ${ }^{[1]}$ Local epidemiological data on eye trauma in our country is limited..$^{[2,3]}$ Multiple types of ocular trauma, ranging in a spectrum from minor injuries treated on an outpatient basis to major eye injuries requiring hospitalization, present to the emergency department (ED). Superficial corneal foreign bodies (SCFB) are common injuries presenting to the ED. ${ }^{[4]}$ SCFBs can be removed in the ED with minimal trauma in an aseptic method with adequate topical anesthesia.

The aim of this study was to describe the epidemiology of eye injuries caused by FBs, identify the nature and characteristics of the injuries and treatment(s) rendered, and determine the clinical strategies for the prevention and management of ocular trauma.

\section{MATERIALS AND METHODS}

This study was carried out as a retrospective chart review in the ED of a tertiary care university hospital with an annual census of approximately 80,000 adult patient visits. The study was approved by the local ethics committee. The ED hospital records for the previous two years were searched to identify all patients visiting the ED with a complaint of eye trauma related to a FB. All patients in the hospital database, which were coded as FB of eye (T15) and ocular trauma (S05) according to the ICD-10 (International Classification of Diseases 10th revision and Clinical Modification) codes were enrolled into the study.

Demographic data including the patient's age and

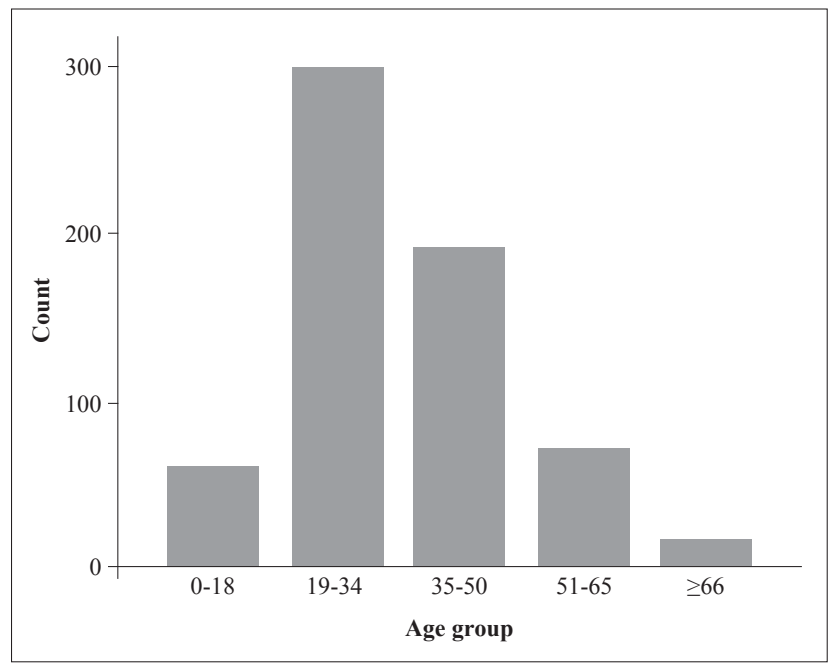

Fig. 1. Distribution of patients by age groups at 15 -year intervals. sex, the affected eye, presence of bilateral injury, timing of the injury and presentation, type of injury (open- or closed-globe injuries), and source of FB were recorded. In addition to details about management in the ED, including the clinical findings on slitlamp examination, the need for hospital admission and ophthalmology consultation, the types of procedures done as part of the treatment (which could include procedures such as irrigation, FB removal and surgical operations), and the long-term complications were also recorded.

Data were analyzed with the SPSS 16.0 for Windows statistical package. The continuous data were presented as mean $\pm \mathrm{SD}$ and the categorical data were presented as frequencies and percentiles. Univariate analyses between two groups for categorical data were performed by chi-square test. A two-sided $\mathrm{p}$ value $<0.05$ was considered as significant.

\section{RESULTS}

The hospital database identified 476 patients according to the specified ICD-10 codes. $83 \%(n=398)$ of the patients were male and $17 \%(n=78)$ female. The male-to-female ratio was $5: 1$. The mean age of the patients included in this study was $34.16 \pm 14.02$ years (range: 1-88 years). The age groups were subdivided into children (0-18) and adult groups, and adults were subdivided into groups at 15 -year intervals. The majority of the patients $(77.4 \%, \mathrm{n}=367)$ were aged 19 to 50 years, while $9.5 \%(\mathrm{n}=45)$ were aged 18 years or younger (Fig. 1). With respect to the time interval from injury to presentation at the department, 52.9\% $(\mathrm{n}=252)$ presented within 6 hours of the injury, and $34.4 \%(\mathrm{n}=164)$ presented within 24 hours (Fig. 2).

Fifty percent $(\mathrm{n}=238)$ of the patients sustained injuries to the right eye, $47.9 \%(n=228)$ had injuries in-

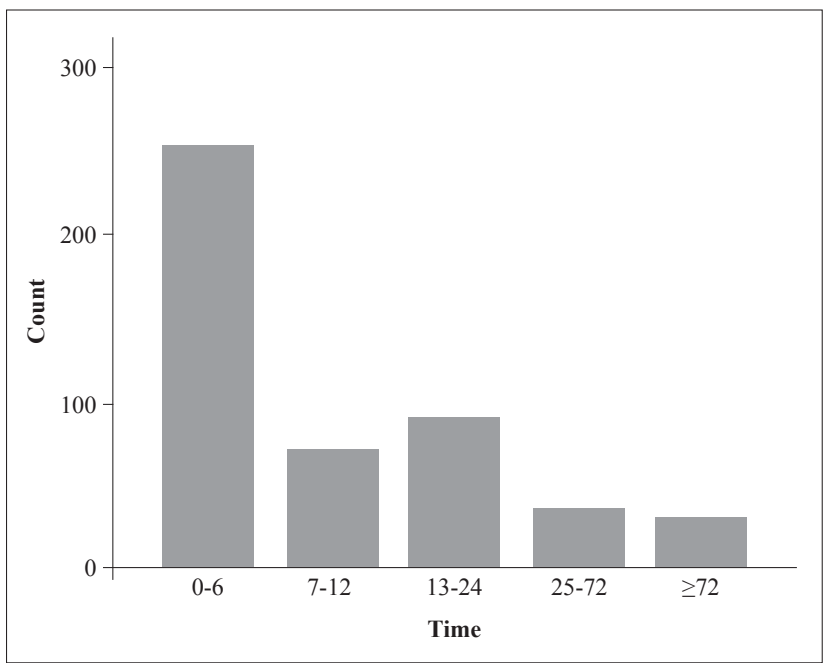

Fig. 2. Time interval between injury and presentation. 
Table 1. Injury types among patients

\begin{tabular}{lc}
\hline Injury type & $\mathrm{n}(\%)$ \\
\hline Affected eye & \\
Right & $238(50)$ \\
Left & $228(47.9)$ \\
Bilateral & $10(1.6)$ \\
Open-globe injury & $46(9.7)$ \\
Intraocular foreign body & $42(8.8)$ \\
Closed-globe injury & $430(90.3)$ \\
Superficial corneal foreign body & $360(72.6)$ \\
Under eyelid & $28(5.9)$ \\
No foreign body & $42(11.8)$ \\
Corneal epithelial defect & \\
Yes & $278(58.4)$ \\
No & $198(41.6)$ \\
\hline
\end{tabular}

Table 2. Foreign bodies found in eyes

\begin{tabular}{lc}
\hline Foreign body & $\mathrm{n}(\%)$ \\
\hline Metal fragments & $179(37.6)$ \\
Dust & $148(31.1)$ \\
Wood splinter & $49(10.3)$ \\
Household chemicals & $26(5.5)$ \\
Finger and nail tap & \\
$25(5.3)$ & \\
Plastic & $14(2.9)$ \\
Glass & $11(2.3)$ \\
Plant & $11(2.3)$ \\
Stone fragments & $9(1.9)$ \\
Insects & $4(0.8)$ \\
\hline
\end{tabular}

Table 3. Long-term complications seen after treatment

\begin{tabular}{ll}
\hline Complication & $\mathrm{n}(\%)$ \\
\hline Keratitis & $4(0.8)$ \\
Cataract & $3(0.6)$ \\
Decreased visual acuity & $2(0.4)$ \\
Retinal detachment & $1(0.2)$ \\
Hyphema & $1(0.2)$ \\
\hline
\end{tabular}

volving the left eye, and $1.6 \%(n=10)$ of the patients had bilateral injuries. $9.7 \%(n=46)$ of the eyes were diagnosed to have an open-globe injury with perforation, and $8.8 \%(\mathrm{n}=42)$ had intraocular FBs, while the rest $(90.3 \%, \mathrm{n}=430)$ were closed-globe injuries with or without SCFBs. In the eye examination, $72.6 \%$ $(n=360)$ of the patients had a SCFB: $18.5 \%(n=88)$ of them were in the central area of the cornea and 5.9\% $(n=28)$ were under the eyelid; $3.4 \%(n=16)$ of the patients had more than one FB. Slit-lamp examination with cobalt blue filter after coloring the eye with fluorescein dye revealed corneal epithelial defects in $58.4 \%(n=278)$ of the patients (Table 1$)$.
The most common FBs causing an injury were metal fragments $(37.6 \%, \mathrm{n}=179)$ and dust $(31.1 \%$, $\mathrm{n}=148)$. The other FBs and injury mechanisms are shown in Table 2 . The majority of the patients $(72.1 \%$, $\mathrm{n}=369$ ) had sustained work-related injuries. Some patients had chemical exposure. Since these patients had symptoms of FB sensation, they were coded as T15 according to the ICD-10 codes and were included in the study group. Most of the chemicals were household cleaning products and soaps.

In the ED, $42.4 \%(n=202)$ of the patients were consulted to ophthalmology, and the remaining patients were treated by the emergency physicians. The most common procedure was the removal of FBs, and the most common methods were removal of the FB with a sharp needle after achieving topical anesthesia (48.3\%, $\mathrm{n}=230)$ and irrigation of the eye $(25.4 \%, \mathrm{n}=121)$. All patients were prescribed topical antibiotics upon discharge from the ED. Only $10 \%(n=48)$ of the patients required hospital admission for their eye injury, and $8.7 \%(n=42)$ of them required operative management. Long-term complications were seen in $2.3 \%(n=11)$ of the patients, and are listed in Table 3 . All patients in whom a complication occurred were consulted to ophthalmology, and none of the patients with FBs treated by the emergency physicians resulted in a long-term complication $(p=0.008)$. Most of the complications ( 9 of 11) occurred in patients with globe perforation. The effects of other factors on the complication rate were not statistically significant (Table 4).

\section{DISCUSSION}

Injury is the most common reason for eye-related ED visits, and most eye injuries seen in the ED are

Table 4. Factors that can affect the complication rate

\begin{tabular}{lcc}
\hline & \multicolumn{2}{c}{ Complication } \\
\cline { 2 - 3 } & Yes (\%) & $\mathrm{p}$ \\
\hline Corneal abrasion & $6(1.3)$ & 0.793 \\
$\quad$ Yes & $5(1.1)$ & \\
$\quad$ No & $9(1.9)$ & $\mathbf{0 . 0 0 0}$ \\
Globe perforation & $2(0.4)$ & \\
$\quad$ Yes & & \\
$\quad$ No & $4(0.8)$ & 0.339 \\
Defect location & $7(1.5)$ & \\
$\quad$ Central (on pupil) & & \\
$\quad$ Non-central & $7(1.5)$ & 0.547 \\
Foreign body & $1(0.2)$ & \\
$\quad$ Solitary & $3(0.6)$ & \\
$\quad$ Multiple & $11(2.3)$ & $\mathbf{0 . 0 0 8}$ \\
$\quad$ None & 0 & \\
Consultation & \\
$\quad$ Yes & \\
$\quad$ No &
\end{tabular}


minor. Approximately 1 million eye injury-related ED visits occur each year in the United States, representing less than $2 \%$ of all ED visits; most of these injuries do not require hospitalization and likely result in no visual impairment. ${ }^{[4]}$ Since the injuries are commonly superficial, it would seem reasonable to suggest that the burden of eye injuries was more commonly on the health system and economy rather than on the patient's quality of life. However, despite their minimal long-term morbidity, ocular trauma is associated with psycho-morbidity and problems of adjustment. ${ }^{[5]}$ Thus, it is important to consider the full spectrum of eye injuries.

It is commonly recognized that young adult males are more prone to ocular trauma because of the relatively higher tendency for risk-taking behavior and the higher proportion of work-, assault- and sports-related eye injuries, in which there is a significant male preponderance. Most studies in the existing literature have shown that male patients formed the overwhelming majority of patients presenting with eye injuries, ranging from $70 \%$ to $87 \%$ of all ocular trauma. ${ }^{[6-11]}$ Similar to the literature, $83 \%$ of the patients in the present study were male and the mean age was 34.16 years, and this corresponds to most other studies, which reported a mean age of about 30 years. ${ }^{[4,6,10,11]}$ When we considered the setting of the injury, $72.1 \%$ of the patients had work-related injuries, and this result is similar to the preexisting literature. ${ }^{[6,10,11]}$ It is also well-known that most eye injuries are preventable with the appropriate use of protective eyewear, yet the use of such equipment is often infrequent. The use of eye protection was not determined in the present study; however, it was thought to be low because of the high work-related injury incidence.

Many studies in the literature have focused on eye injuries that were serious enough to require hospital admission. While those injuries are the most likely to be visually disabling, they are also rare and therefore represent only a small part of the problem. ${ }^{[12-15]}$ Our study has presented the epidemiology of eye injuries treated in the ED. In contrast to existing studies that provide estimates of the rate of severe eye injury only, our study provides a more comprehensive estimate by including a preponderance of such injuries, that is, those not requiring hospitalization. Our results were similar to the other studies including ED patients. ${ }^{[4]}$ Only $10 \%$ of the patients required hospital admission for their eye injury, and long-term complications were seen in only $2.3 \%$ of the patients in the present study.

The great majority of SCFBs are metallic, followed by stone fragments and wood. ${ }^{[16]}$ The present study revealed similar results. Since the majority of injuries occurred at work while cutting and welding metals, the commonest FBs were metal fragments, which sprayed into the eyes of workers who were not wearing protective devices.

The exact proportion of all eye injuries seen directly by ophthalmologists in EDs is unknown; however, it would not be surprising if the number is low. In the present study, $57.6 \%$ of the patients were treated by emergency physicians without any complication. When evaluating a patient with FB in the eye, two major questions to be answered by the physician are: whether the FB is superficial or intraocular and whether the SCFB can be removed in the ED. If an intraocular FB is suspected, ophthalmology consultation should be done immediately. ${ }^{[17]}$ All patients with perforated eye injury with or without FB were consulted to ophthalmology in the present study. If an uncomplicated SCFB is discovered and the visual acuity and other findings in the slit-lamp examination are normal, the emergency physician should attempt the removal. After the eye is anesthetized with topical anesthetic, successful removal can often be achieved by irrigation or with a 25 -gauge needle. ${ }^{[17]}$ While multiple nondeeply embedded FBs such as dust can be removed successfully with irrigation, the metal fragments usually require needle manipulation. In the present study, $48.3 \%$ of patients required needle removal.

If dealt with appropriately, there are usually no long-term sequelae and recovery is rapid, over 24-72 hours. It has been shown that delay in rehabilitation following non-penetrating SCFB is related to two factors: the size of the corneal epithelial defect following FB removal and inadequate removal of corneal rust. ${ }^{[18]}$ In the present study, corneal epithelial defects were found in $58.4 \%$ of the patients; however, the size of the defects and the adequacy of rust removal were not determined.

Once the FB is removed, topical antibiotics may be given for all patients with or without corneal abrasions. In a prospective study, removed FBs were cultured and $32.7 \%$ showed positive results, mostly staphylococcal and streptococcal species, therefore mandating treatment with broad-spectrum antibiotics. [16] Patching is not generally recommended, because studies have shown no significant difference in patient comfort or the healing rate. ${ }^{[19,20]}$ Topical anesthetics should also be avoided, because these agents may hide pain associated with retained FB or corneal ulceration. ${ }^{[21]}$ In the present study, all patients were prescribed topical antibiotics upon discharge from the ED, and no long-term complications were seen in patients treated by the ED physicians.

In conclusion, ocular trauma in this study involved mainly young healthy males who had sustained workrelated injuries, which can cause significant morbidity. Nevertheless, most occupational accidents can be 
avoided with utilization of better protective devices in order to reduce the incidence of injuries and socioeconomic damage. Finally, given the large number of eye injuries seen in EDs, emergency medicine colleagues should train themselves in order to appropriately recognize, treat and refer the SCFB injuries seen in the ED.

\section{REFERENCES}

1. Wong TY, Klein BE, Klein R. The prevalence and 5-year incidence of ocular trauma. The Beaver Dam Eye Study. Ophthalmology 2000;107:2196-202. CrossRef

2. Akdur O, Ozkan S, Erkılıc K, Durukan P, Duman A, Ikizceli I. Evaluation of ocular trauma cases presenting to the emergency department JAEM 2009;8:47-50

3. Ustundag M, Orak M, Guloglu C, Sayhan MB, Ozhasenekler A. Retrospective evaluation of eye injury victims presented to emergency department. Turk J Emerg Med 2007;7:64-7.

4. McGwin G Jr, Owsley C. Incidence of emergency department-treated eye injury in the United States. Arch Ophthalmol 2005;123:662-6. CrossRef

5. Alexander DA, Kemp RV, Klein S, Forrester JV. Psychiatric sequelae and psychosocial adjustment following ocular trauma: a retrospective pilot study. $\mathrm{Br} \mathrm{J}$ Ophthalmol 2001;85:560-2. CrossRef

6. Woo JH, Sundar G. Eye injuries in Singapore-don't risk it. Do more. A prospective study. Ann Acad Med Singapore 2006;35:706-18.

7. Glynn RJ, Seddon JM, Berlin BM. The incidence of eye injuries in New England adults. Arch Ophthalmol 1988;106:7859. CrossRef

8. Katz J, Tielsch JM. Lifetime prevalence of ocular injuries from the Baltimore Eye Survey. Arch Ophthalmol 1993;111:1564-8. CrossRef

9. Wong TY, Smith GS, Lincoln AE, Tielsch JM. Ocular trauma in the United States Army: hospitalization records from 1985 through 1994. Am J Ophthalmol 2000;129:645-50. CrossRef

10. Schein OD, Hibberd PL, Shingleton BJ, Kunzweiler T, Frambach DA, Seddon JM, et al. The spectrum and burden of ocular injury. Ophthalmology 1988;95:300-5.

11. Macewen CJ. Eye injuries: a prospective survey of 5671 cases. Br J Ophthalmol 1989;73:888-94. CrossRef

12. Desai P, MacEwen CJ, Baines P, Minassian DC. Incidence of cases of ocular trauma admitted to hospital and incidence of blinding outcome. Br J Ophthalmol 1996;80:592-6. CrossRef

13. Klopfer J, Tielsch JM, Vitale S, See LC, Canner JK. Ocular trauma in the United States. Eye injuries resulting in hospitalization, 1984 through 1987. Arch Ophthalmol 1992;110:83842. CrossRef

14. Fong LP. Eye injuries in Victoria, Australia. Med J Aust. 1995;162:64-8.

15. Wong TY, Tielsch JM. A population-based study on the incidence of severe ocular trauma in Singapore. Am J Ophthalmol 1999; 128:345-51. CrossRef

16. Macedo Filho ET, Lago A, Duarte K, Liang SJ, Lima AL, Freitas D. Superficial corneal foreign body: laboratory and epidemiologic aspects. Arq Bras Oftalmol 2005;68:821-3.

17. Babineau MR, Sanchez LD. Ophthalmologic procedures in the emergency department. Emerg Med Clin North Am 2008;26:17-34, v-vi. CrossRef

18. Jayamanne DG, Bell RW. Non-penetrating corneal foreign body injuries: factors affecting delay in rehabilitation of patients. J Accid Emerg Med 1994;11:195-7. CrossRef

19. Arbour JD, Brunette I, Boisjoly HM, Shi ZH, Dumas J, Guertin MC. Should we patch corneal erosions? Arch Ophthalmol 1997; 115:313-7. CrossRef

20. Wilson SA, Last A. Management of corneal abrasions. Am Fam Physician 2004;70:123-8.

21. Newell SW. Management of corneal foreign bodies. Am Fam Physician 1985;31:149-56. 